\title{
Central and Peripheral Administration of Secretin Inhibits Food Intake in Mice through the Activation of the Melanocortin System
}

\author{
Carrie Yuen Yee Cheng ${ }^{1,2}$, Jessica Yan Shuen Chu ${ }^{1,2}$ and Billy Kwok Chong Chow, \\ 'School of Biological Sciences, The University of Hong Kong, Pokfulam, Hong Kong SAR, China
}

\begin{abstract}
Secretin (Sct) is released into the circulation postprandially from the duodenal S-cells. The major functions of Sct originated from the gastrointestinal system are to delay gastric emptying, stimulate fluid secretion from pancreas and liver, and hence optimize the digestion process. In recent years, Sct and its receptor (Sctr) have been identified in discrete nuclei of the hypothalamus, including the paraventricular nucleus (PVN) and the arcuate nucleus (Arc). These nuclei are the primary brain sites that are engaged in regulating body energy homeostasis, thus providing anatomical evidence to support a functional role of Sct in appetite control. In this study, the effect of Sct on feeding behavior was investigated using wild-type (Wt), Sct ${ }^{-1-}$, and secretin receptor-deficient $\left(\mathrm{Sctr}^{-1-}\right.$ ) mice. We found that both central and peripheral administration of Sct could induce Fos expression in the PVN and Arc, suggesting the activation of hypothalamic feeding centers by this peptide. Consistent with this notion, Sct was found to increase thyrotropin-releasing hormone and melanocortin-4 receptor (Mc4r) transcripts in the PVN, and augment proopiomelanocortin, but reduces agouti-related protein mRNA expression in the Arc. Injection of Sct was able to suppress food intake in wt mice, but not in $\mathrm{Sctr}^{-1-}$ mice, and that this effect was abolished upon pretreatment with SHU9I 19, an antagonist for Mc4r. In summary, our data suggest for the first time that Sct is an anorectic peptide, and that this function is mediated by the melanocortin system.

Neuropsychopharmacology (201I) 36, 459-47I; doi:10.1038/npp.2010.178; published online 6 October 2010
\end{abstract}

Keywords: arcuate nucleus; feeding; melanocortin system; proopiomelanocortin; secretin; secretin receptor

\section{INTRODUCTION}

Energy homeostasis involves a coordinated control on energy input, release, usage, and storage by a complex system consisting of central and peripheral signals. Food intake is the major source of energy input. However, disturbance of this process such as overeating results in obesity, which is the biggest health issue in today's societies. There are more than 1 billion adults classified as being overweight and at least 300 million as obese (WHO, 2010). The growing awareness of health issues related to obesity has prompted research into the mechanisms underlying energy homeostasis. Over the past 30 years, gut peptides have been implicated to have key roles in regulating energy homeostasis and food appetite. The well established gut hormones controlling energy homeostasis includes ghrelin

*Correspondence: Professor BKC Chow, School of Biological Sciences, The University of Hong Kong, 4NOI, Kadoorie Biological Sciences Building, Pokfulam, Hong Kong SAR, China, Tel: + 852 22990850, Fax: 852 25599| |4, E-mail: bkcc@hkusua.hku.hk

2Jessica YS Chu and Carrie YY Cheng contributed equally to the overall design and execution of the experiments described here.

Received I5 June 2010; revised 16 August 2010; accepted 30 August 2010
(Nakazato et al, 2001; Tamura et al, 2002; Tschop et al, 2000; Wang et al, 2002; Wren et al, 2001; Wren et al, 2000), cholecystokinin (Cck; Beglinger et al, 2001; Gibbs et al, 1973; Hewson et al, 1988; Kissileff et al, 1981), pancreatic polypeptide (PP) (Asakawa et al, 2003; Batterham et al, 2003a, b; Malaisse-Lagae et al, 1977; Ueno et al, 1999), peptide YY (Batterham et al, 2003a, b; Batterham et al, 2002; Challis et al, 2003), glucagon-like peptide-1 (Glp1; Meeran et al, 1999; Tang-Christensen et al, 2001; Turton et al, 1996; Verdich et al, 2001; Yamamoto et al, 2003), and oxyntomodulin (Cohen et al, 2003; Dakin et al, 2002; Dakin et al, 2001; Dakin et al, 2004).

Secretin (Sct), a 27-amino acid peptide hormone primarily produced from duodenal $S$ cells, belongs to the vasoactive intestinal polypeptide/ Sct/ glucagon/ growth hormone-releasing hormone peptide family (Vaudry et al, 2000). The physiological role of this gastrointestinal hormone is to provide an optimum condition for food digestion in the intestine by regulating gastric secretion and emptying (Gerber and Payne, 1996; Jin et al, 1994; Shiratori et al, 1992; You and Chey, 1987), stimulating the release of bicarbonate-enriched fluid from the pancreas (Gray et al, 1988; Konturek et al, 2003) and bile from the liver (Bayliss and Starling, 1902; Kanno et al, 2001). Apart 
from the well studied gastrointestinal function, the role of Sct in metabolism and energy homeostasis has also been suggested since 1974 (Boden et al, 1974). It was found that Sct could stimulate insulin secretion after a prolonged glycemic stimuluation (Chisholm et al, 1969; Diaco et al, 1971; Kofod, 1986; Kraegen et al, 1970; Lerner and Porte, 1970, 1972), suggesting that Sct is a potential incretin after an oral glucose load, although it was found later that Glp1 and gastric inhibitory peptide are more potent in these activities. Sct has been suggested to function as lipolytic agent in raising adenylate cyclase activity and lipolytic activity of adipose tissue lipase in isolated fat cells (Rodbell et al, 1970; Rudman and Del Rio, 1969). The effect of Sct in appetite control has also been reported in several early studies, however, inconsistent results were observed in different animal models. Sct was found to decrease appetite in fasted sheep (Grovum, 1981) after intravenous injection but not in rats (Gibbs et al, 1973; Glick et al, 1971).

Recently, there was an increasing amount of evidence to indicate a neuroactive role of Sct in the central nervous system (CNS). As a neuropeptide, the expression of Sct and secretin receptor (Sctr) was detected in various brain regions (Charlton et al, 1981; Chu et al, 2006; Köves et al, 2004; Lee et al, 2005; Nussdorfer et al, 2000; O'Donohue et al, 1981; Tay et al, 2004; Welch et al, 2004a, b), including hypothalamus, cerebellum, hippocampus, and brain stem. Specific areas in the hypothalamus and brainstem are important in integrating nutritional signals and hence regarded as important areas in controlling appetite control and energy homeostasis. In the hypothalamus, Sct was found within the appetite-relating nuclei including paraventricular nucleus (PVN) and supraoptic nucleus (SON; Chu et al, 2006; Welch et al, 2004a,b). In the brainstem, real-time PCR (RT-PCR) revealed the presence of Sct and Sctr mRNAs in the area postrema (AP) and nucleus of the solitary tract (NTS; Tay et al, 2004), where they are crucial in relaying peripheral signals from the gut to the hypothalamus.

Based on the findings that Sct is released into the circulation postprandially and is found together with its receptor in appetite regulating centers within the CNS, we hypothesize here that Sct can inhibit food intake. In this study, we investigated the potential role of this brain-gut peptide in food intake regulation initially by measuring food intake after central and peripheral administrations of Sct in wild-type (wt), $\mathrm{Sctr}^{-1-}$, and $S c t^{-1-}$ mice. The cellular mechanisms were subsequently studied by monitoring neuronal activation of Fos and other known appetite-related neuropeptides upon central and peripheral administration of Sct. Finally, using melanocortin-4 receptor (Mc4r) antagonist, SHU9119, we established a potential link between Sct and the melanocortin (MC) system in modulating feeding behavior.

\section{MATERIALS AND METHODS}

\section{Animal Handling}

The procedures of animal care and handling were in accordance with the protocol approved by the Committee on the Use of Live Animals in Teaching and Research of the University of Hong Kong. All experiments were carried out using wt and knockout adult male mice $(20-25 \mathrm{~g})$ of N5 generation, which were kept in a temperature-controlled room with a 12-h light/dark cycle. Mice were fed ad libitum with standard rodent chow (no. 5010, Test Diet, IN) and water, unless otherwise stated.

\section{I.c.v Cannulation and Injection}

Mice were implanted with a permanent 11-mm-long, 21-gauge stainless steel cannula projecting to the lateral ventricle and/or PVN, according to the co-ordinates of Paxinos and Franklin (2001). (coordinates relative to bregma were as follows: i.c.v, $1.00 \mathrm{~mm}$ lateral, $0.5 \mathrm{~mm}$ posterior, and $2.0 \mathrm{~mm}$ ventral; PVN, $0.1 \mathrm{~mm}$ lateral, $0.8 \mathrm{~mm}$ posterior, and $4.7 \mathrm{~mm}$ ventral). Cannula placement was confirmed by injection of a dye and injections were done using PE-10 tubing attached to an injector and a 10- $\mu \mathrm{l}$ Hamilton syringe. All animals were allowed to recover from surgery for a minimum of 5-7 days, then artificial cerebrospinal fluid (aCSF; prepared according to Alzet protocol, $5 \mu \mathrm{l})$ and Sct $(454 \mathrm{ng} / 5 \mu \mathrm{l} ; 60677$; AnaSpec, San Jose, CA) were injected into the lateral ventricle, whereas SHU9119 (537 ng/2 $\mu$ l; H-3952; Bachem, Bubendorf, Switzerland) were injected into the PVN.

\section{Feeding Studies}

Experiment 1: Effects of Sct on food intake in fasted mice. Experimental mice (wt, Sct ${ }^{-1-}$, and $\mathrm{Sctr}^{-1-}$ ) were fasted for $18 \mathrm{~h}$ before study. During the early light phase $(1000 \mathrm{~h})$, mice were received i.c.v.-Sct $(0.15$ and $1 \mathrm{nmol})$ or i.p.-Sct $(5 \mathrm{nmol})$, whereas control mice received either i.c.v.-aCSF or i.p.-PBS. After injection, mice were individually put in metabolic cages provided with preweighted amount of chow. Cumulative food intake was monitored at specific time points after injection.

Experiment 2: Effects of Sct on nocturnal food intake in ad libitum fed mice. The dark phase is the normal feeding time and thus inhibition of food intake observed is considered more physiologically relevant than the fasting/ refeeding paradigm. Mice (wt, $\mathrm{Sct}^{-/-}$, and $\mathrm{Sctr}^{-/-}$) were subject to i.c.v.-Sct $(0.15$ and $1 \mathrm{nmol})$ or i.c.v.-aCSF before lights out $(1900 \mathrm{~h})$, and cumulative food intakes were measured $1,2,4,6,8$, and $24 \mathrm{~h}$ after injection.

Experiment 3: Effects of prolonged administration of Sct on food intake. Mice (wt, Sct ${ }^{-1-}$, and $\mathrm{Sctr}^{-1-}$ ) were continuous infused with Sct $(2.5 \mathrm{nmol} / \mathrm{kg} /$ day $)$ or vehicle PBS by intraperitoneal implantation of 7-day mini-osmotic pumps (model 1007D, $0.5 \mu \mathrm{l} / \mathrm{h}$ for 7 days; Alzet, CA). One day after surgery, mice were returned to their home cage with preweighted chow, and food intakes were measured daily from day 2 to day 10 .

Experiment 4: Effects of SHU9119 on Sct-induced inhibition of feeding. Mice (wt, Sct ${ }^{-/-}$, and $S c t r^{-/-}$) were fasted for $18 \mathrm{~h}$ and were injected with SHU9119 (50 pmol) into the PVN immediately before i.c.v.-Sct $(0.15 \mathrm{nmol})$ or i.p.-Sct $(5 \mathrm{nmol})$ at $1000 \mathrm{~h}$. Cumulative food intake was measured every $30 \mathrm{~min}$ up to $2 \mathrm{~h}$ post injection.

\section{Conditioned Taste Aversion}

Mice were accustomed to the injection paradigm by daily handling and i.p. injections for 5 days and they were 
randomized into three treatment groups $(n=10$ each): vehicle (PBS), Sct $(5 \mathrm{nmol})$, and $\mathrm{LiCl}(0.3 \mathrm{~mol} / \mathrm{l})$. On the conditioning day, mice were given two bottles of a novel $0.15 \%$ saccharin solution for $30 \mathrm{~min}$ period and were then injected i.p. with PBS, Sct, or LiCl. On the next day, mice were presented with water and $0.15 \%$ saccharin solution, and their water and saccharin intake measured at $30 \mathrm{~min}$ after presentation.

\section{Immunohistochemical Staining}

Brains from mice were removed and fixed in 3.7\% formalin, embedded in paraffin, and sectioned $(7 \mu \mathrm{m})$. Sections were dewaxed and rehydrated in graded ethanol. Endogenous peroxidase activity was blocked by treatment with $3 \%$ hydrogen peroxide in methanol. Microwave antigen retrieval was performed with citric acid buffer at $\mathrm{pH} 6.0$ for $10 \mathrm{~min}$, followed by $5 \%$ normal goat serum for $2 \mathrm{~h}$. Sections were then incubated with rabbit anti-Sct antibody (Ab; 1:500 dilution; Chemicon, Millipore, Billerica, MA), rabbit anti-Sctr Ab (1:500 dilution; Invitrogen, Carlsbad, CA), or rabbit anti-Fos Ab (1:500 dilution; Santa Cruz Biotechnology, Santa Cruz, CA) overnight at $4{ }^{\circ} \mathrm{C}$. Knockout mouse brain sections were used as negative controls $\left(\mathrm{Sct}^{-1-}\right.$ for Sct and $\mathrm{Sctr}^{-l-}$ for Sctr staining). The immunoreactive signals were detected by using the Vectastain ABC Elite kit (PK6101, Vector Laboratories, Burlingame, CA). In brief, after several washes with $\mathrm{PBS}$, sections were treated with antirabbit biotinylated secondary $\mathrm{Ab}$ ( $1: 200$ dilution), followed by application of the avidin-biotin-horseradish peroxidase reagent. Finally, signals were visualized in light brown color by using the $1 \times$ DAB substrates (Roche Diagnostics, Shanghai, China) and counterstained with hematoxylin (Zymed Laboratories, San Francisco, CA).

\section{Fos Immunohistochemistry}

Mice were randomly assigned into two groups. One group received i.c.v.-aCSF or -Sct and the other group received i.p.-PBS or -Sct. To prevent the induction of Fos expression due to feeding, food was immediately removed from the cages of injected mice. After $30 \mathrm{~min}$ i.c.v. injection and $2 \mathrm{~h}$ after i.p. injection, mice were anesthetized (Chloralhydrat, $0.01 \mathrm{mg} / \mathrm{kg}$ body weight, i.p.) and then decapitated. The staining procedures were identical in those described in immunohistochemistry staining except rabbit anti-Fos Ab (1:500 dilution; Santa Cruz Biotechnology) was used. The number of reactive cells was counted from both sides of the brain and the boundaries of neuroanatomical sites of interest were defined according to the coordinates based on Paxinos and Watson. The sum of the number of Fos immunoreactive cells on both sides was calculated in each animal and used for the statistical analysis.

\section{Double Immunofluorescence Staining}

Paraffin-embedded brain sections $(7 \mu \mathrm{m})$ were deparaffinizated, rehydrated, and permeabilized in PBS-BT (phosphate-buffered saline supplemented with $2 \%$ bovine serum albumin and $0.5 \%$ Triton X-100). After blocking with donkey serum for $2 \mathrm{~h}$, the sections were incubated overnight with rabbit anti-Sctr $\mathrm{Ab}$ (1:500 dilution; Invitrogen) or rabbit anti-Fos Ab (1:500 dilution; Santa Cruz Biotechnology), followed by Alexa Fluor 488 donkey antirabbit IgG (1:300 dilution; Invitrogen). The sections were washed thoroughly with PBS-BT and blocked again by normal goat serum. Subsequently, the sections were incubated at $4{ }^{\circ} \mathrm{C}$ overnight with rabbit anti-proopiomelanocortin (Pomc) Ab (1:5000 dilution; Phoenix Pharmaceuticals, Inc. Burlingame, CA), and then by Alexa Fluor 555 goat anti-rabbit IgG ( $1: 300$ dilution; Molecular Probes, Invitrogen). Images were captured with the Zeiss LSM 510 Meta computerized image analysis system.

\section{In Situ Hybridization}

The labeled RNA probes for mouse Sct (456bp; nt -7 to + 449 relative to $\mathrm{ATG})$ and $\operatorname{Sctr}(501 \mathrm{bp} ; \mathrm{nt}-33$ to +468 relative to ATG) were generated by the DIG RNA labeling kit (Roche). Paraffin-embedded brain sections (7- $\mu \mathrm{m}$ thick) were deparaffinizated and rehydrated. The sections were first treated with $0.2 \mathrm{M} \mathrm{HCl}, 5 \mu \mathrm{g} / \mathrm{ml}$ and Proteinase $\mathrm{K}$, then acetylated and covered with prehybridization buffer

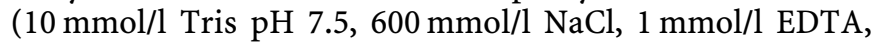
$0.25 \%$ SDS, $10 \%$ dextran sulfate, $1 \times$ Denhardt's solution, $200 \mu \mathrm{g} / \mathrm{ml}$ yeast tRNA, $50 \%$ formamide) in a humidified chamber at $50^{\circ} \mathrm{C}$. Hybridization was performed overnight at $50^{\circ} \mathrm{C}$ with the same buffer with the labeled antisense Sct or Sctr probes $(0.2 \mathrm{ng} / \mu \mathrm{l})$. For negative controls, an antisense probe without DIG-labeling $(30 \times)$ was used to compete with the labeled probes. On the next day, sections were washed in $2 \times \mathrm{SSC}$ at $50^{\circ} \mathrm{C}$ and treated with RNase A $(4 \mu \mathrm{g} / \mathrm{ml})$ at $37^{\circ} \mathrm{C}$ for $30 \mathrm{~min}$ followed by $1 \times \mathrm{SSC}$, and $0.1 \times$ SCC washing. After washing with $1 \times$ buffer 1 ( $100 \mathrm{mM}$ Tris and $150 \mathrm{mM} \mathrm{NaCl}, \mathrm{pH} 7.5$ ), sections were blocked with $3 \%$ FBS for $1 \mathrm{~h}$ and incubated with the antiDIG Ab (dilution 1:500; Roche) overnight at $4{ }^{\circ} \mathrm{C}$. On the third day, after rinsing for $10 \mathrm{~min}$ in buffer 1 and $10 \mathrm{~min}$ in buffer $2\left(100 \mathrm{mM}\right.$ Tris-HCL, $50 \mathrm{mM} \mathrm{MgCl}_{2}$, and $100 \mathrm{mM}$ $\mathrm{NaCl}, \mathrm{pH}$ 9.5), NBT/BCIP (Roche) was used as the chromogenic substrate.

\section{Laser-Capture Microdissection (LCM) and RT-PCR}

Mice were fasted for $18 \mathrm{~h}$ and were i.c.v.- or i.p.-injected with Sct ( 0.15 and $5 \mathrm{nmol}$, respectively). At a specific time after the i.c.v.-Sct $(1 \mathrm{~h})$ or i.p.-Sct $(4 \mathrm{~h})$, brains of control and treated groups were isolated, embedded in OCT compound (Sarura Finetek, Torrance, CA) and stored at $-20^{\circ} \mathrm{C}$. The frozen brains were then sectioned $(8 \mu \mathrm{m})$ using a cryostat microtome (Jung CM3000, Lieca Microsystems, Leitz, Germany) and mounted on plain slices. Brain sections at the level of the arcuate nucleus (Arc) and PVN were stained with hematoxylin and eosin and imaged in the PixCell IIe Laser Capture Microdissection System (Arcturus, Sunnyvale, CA). Target regions including the Arc and PVN were located according to the mouse brain atlas and were captured on CapSure HS LCM Caps (Arcturus). Total RNAs were extracted from Arc and PVN using TriPure isolated reagent (Roche molecular biochemicals, Basel, Switzerland) for the synthesis of first-strand cDNAs. RT-PCR was conducted with a 7300 Real Time PCR System (Applied Biosystems, Warrington, UK) using a SYBR PCR master 
Table I Sequence of the Oligonucleotides used for RT-PCR

\begin{tabular}{|c|c|}
\hline Primer & Sequence $5^{\prime} \rightarrow 3^{\prime}$ \\
\hline Agrp & $\begin{array}{l}\text { AGCTITGGCGGAGGTGCT } \\
\text { GCCACGCGGAGAACGA }\end{array}$ \\
\hline Cart & $\begin{array}{l}\text { GCCAAGGCGGCAACTC } \\
\text { TCTTGCAACGCTTCGATCTG }\end{array}$ \\
\hline Crh & $\begin{array}{l}\text { CCCGCAGCCCTTGAATT } \\
\text { TTCACCCATGCGGATCAGA }\end{array}$ \\
\hline Gapdh & $\begin{array}{l}\text { GGAGAAACCTGCCAAGTA } \\
\text { AAGAGTGGGAGTTGCTGTTG }\end{array}$ \\
\hline Mc4r & $\begin{array}{l}\text { AAGCTGCCCAGATACAACTTATGA } \\
\text { ACGCGTCCAGTACCATAACA }\end{array}$ \\
\hline Npy & $\begin{array}{l}\text { TCCGCTCTGCGACACTACAT } \\
\text { TGCTTICCTTCATTAAGAGGTCTG }\end{array}$ \\
\hline Pomc & $\begin{array}{l}\text { TGAACATCTTTGTCCCCAGAGA } \\
\text { TGCAGAGGCAAACAAGATTGG }\end{array}$ \\
\hline Trh & $\begin{array}{l}\text { CCCAGCCAGTTTGCACTCTT } \\
\text { AGATCAAAGCCAGAGCCATCA }\end{array}$ \\
\hline
\end{tabular}

mix kit (Applied Biosystems). Mouse glyceraldehyde-3phosphate dehydrogenase (Gapdh) mRNA was measured as an internal control and primers used for mouse agoutirelated protein (Agrp), cocaine- and amphetamine-regulated transcript (Cart), corticotropin-releasing hormone (Crh), Gapdh, neuropeptide Y (Npy), Pomc, Mc4r, and thyrotropin-releasing hormone (Trh) are listed in Table 1.

\section{Enzyme Immunoassays (EIA)}

At a specific time $(2,4$, and $6 \mathrm{~h})$ after Ip-Sct in wt mice, blood was collected at the jugular vein. Blood samples were centrifuged at $2000 \mathrm{~g}$ for $5 \mathrm{~min}$ to obtain blood plasma. Sct protein levels in the plasma of control and treated mice were measured using EIA kits (Phoenix Pharmaceuticals, Inc.), according to the manufacturer's instructions.

\section{Statistical Analysis}

All data are shown as means \pm SEM. Deviations between groups were analyzed using PRISM (version 3.0, GraphPad Software, La Jolla, CA). Unpaired $t$-test was performed only when there were two groups, whereas data from more than two groups were analyzed by one-way ANOVA, followed by Dunnett's test.

\section{RESULTS}

\section{Peripheral and Central Injections of Sct Suppress Food Intake in Mice}

In the present study, we postulated that Sct, a postprandially released gut hormone, functions to inhibit food intake. To test this hypothesis, initially, wt, $S_{c t r}{ }^{-1-}$, and $S c t^{-l-}$ mice were used to investigate the effects of Sct on food intake by administrating the peptide through (1) i.p. injection or (2) i.p. implanted mini-osmotic pump. Ip-Sct $(5 \mathrm{nmol})$ significantly reduced fast-induced refeeding when compared with the saline-injected mice. This observed anorectic effect of i.p.-Sct in wt mice was found to be specific to Sct as the inhibition of food intake was not detected in $\mathrm{Sctr}^{-1-}$ mice (Figure 1a), but could be reproduced as in wt mice when Sct was injected in $\mathrm{Sct}^{-1-}$ mice (Figure 1a). To confirm the anorectic effect of Sct, we monitored food intake in these mice models under prolonged peripheral perfusion of Sct via i.p.-implantation of mini-osmotic pumps. During the 7-day effective period of the pump, there were significant reductions in food intake in wt mice (Figure 1b) from days 2-7, whereas after day 7 when the pump was emptied, food intake was found similar to the sham-operated controls. In this study, $\mathrm{Sctr}^{-1-}$ mice were used again as negative controls to show the specific effects of Sct (Figure 1b). In summary, our data clearly show that both acute and chronic peripheral infusions of Sct are effective in inhibiting food intake.

As Sct and Sctr are expressed in the hypothalamus (Charlton et al, 1981; Nussdorfer et al, 2000) where peripheral signals for energy availability are integrated, we next sought to investigate the effects of central Sct on feeding. Our data show that, in both fast-induced refeeding and nocturnal feeding paradigms, i.c.v. injection of Sct suppressed food intake dose-dependently in wt mice. In $18 \mathrm{~h}$ fasted wt mice, i.c.v.-Sct $(0.15$ and $1.00 \mathrm{nmol})$ significantly $(p<0.05)$ reduced food intake in the first $30 \mathrm{~min}$ (Sct, $0.15 \mathrm{nmol}, 0.34 \pm 0.03 \mathrm{~g} ; 1 \mathrm{nmol}, 0.17 \pm 0.03 \mathrm{~g}$; aCSF control, $0.60 \pm 0.08$ g; Figure $2 \mathrm{a}$ ) when compared with the aCSF-injected controls $(1.11 \pm 0.16 \mathrm{~g})$. In the nocturnal free-feeding paradigm, central injection of Sct $(0.15$ and $1.00 \mathrm{nmol}$ ) was carried out in wt, $S c t r{ }^{-1-}$, and $S c t^{-/-}$mice before light out and food intake was monitored at different time points for $24 \mathrm{~h}$. In ad libitum fed wt mice, Sct also caused significant reductions in food intake in a dosedependent manner ( $1 \mathrm{~h}$ : Sct, $0.15 \mathrm{nmol}, 0.15 \pm 0.03 \mathrm{~g} ; 1 \mathrm{nmol}$, $0.17 \pm 0.05 \mathrm{~g} ; \quad$ aCSF control, $0.27 \pm 0.05 \mathrm{~g} ; \quad p<0.05$; Figure 2d). Again, this observed anorectic effect of i.c.v.Sct was not detected in Sctr ${ }^{-1-}$ mice (Figure $2 \mathrm{~b}$ and e), but was reproduced in $\mathrm{Sct}^{-1-}$ mice (Figure $2 \mathrm{c}$ and $\mathrm{f}$ ).

\section{Localizations of Sct and Sctr in Hypothalamic Nuclei that are Involved in Appetite Control}

As central injection of Sct is able to reduce food intake, it is possible that Sct expressed and released in the brain can directly control food appetite. Before testing this hypothesis, immunohistochemistry and in situ hybridization studies were performed to identify the presence of Sct and Sctr expressing neurons in specific nuclei of the hypothalamus that function to regulate food intake. Our results revealed and confirmed (Chu et al, 2006; Welch et al, 2004) the expressions of both Sct and Sctr transcripts (Figure $3 \mathrm{~b}$ ) and proteins (Figure $3 \mathrm{a}$ ) in the Arc and PVN. These data therefore provide neuroanatomical evidence in substantiating the potential functions of Sct and Sctr in regulating feeding behavior. Using double immunofluorescent staining, Sctr was found to colocalize with Pomc neurons within the Arc (Figure 3c), suggesting that Sct would modulate feeding through the activation of Pomc neurons. 
a

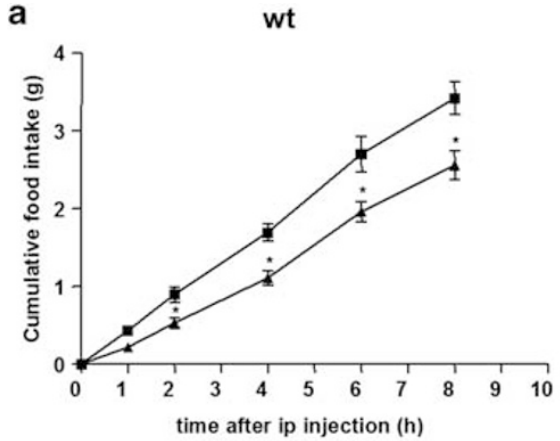

b

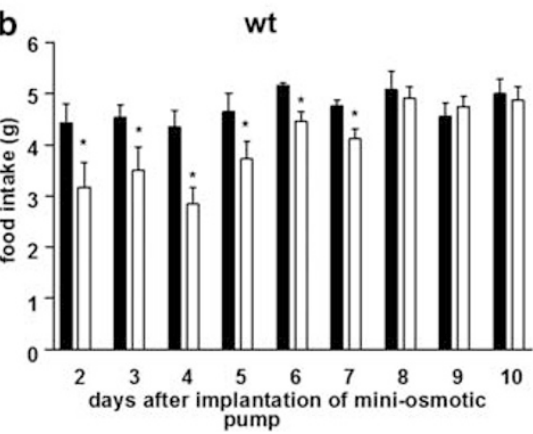

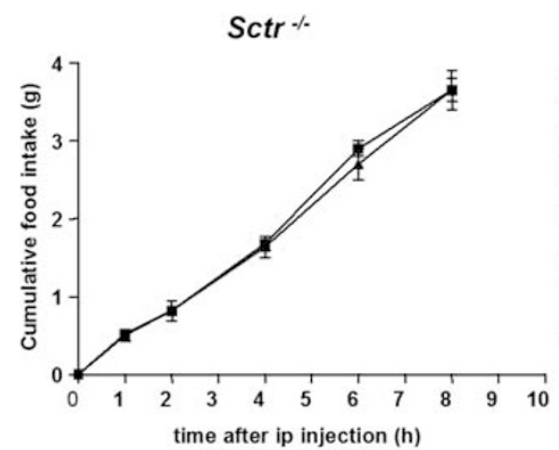

Sctr $\%$

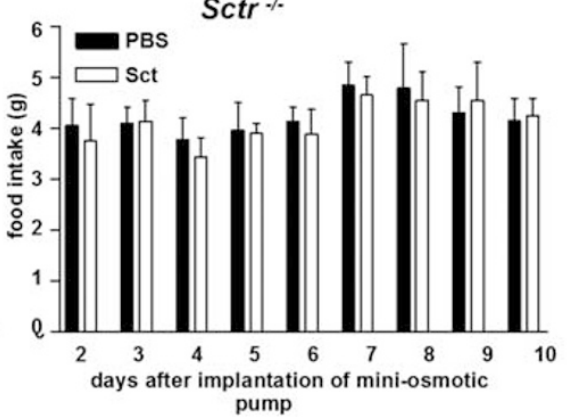

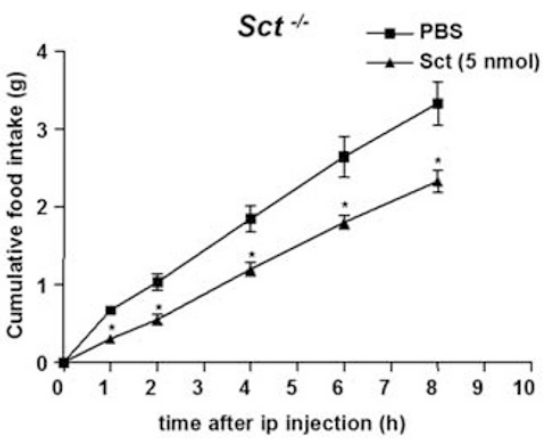

c

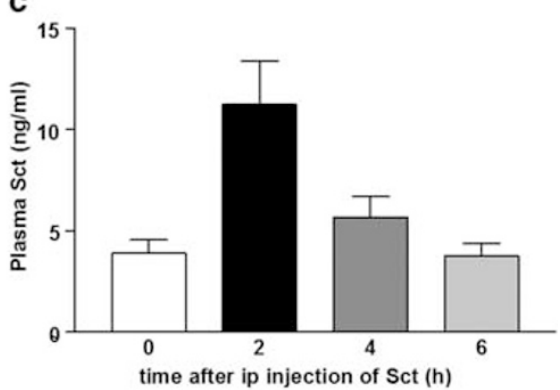

Figure I Anorectic effect of peripheral Sct administration in mice. (a) Time-course study on the effects of i.p.-Sct or i.p.-PBS (vehicle) on cumulative food intake at different time (I, 2, 4, 6, and $8 \mathrm{~h}$ ) in $18 \mathrm{~h}$ fasted $\mathrm{wt}, \mathrm{Sctr}^{-1-}$, and Sct ${ }^{-1-}$ mice. Data are expressed as the means $\pm \mathrm{SEM}$ ( $\left.n=10 / \mathrm{group}\right)$. (b) Effects of continuous Sct or PBS infusion by i.p.-implantation of mini-osmotic pump on daily food intake in wt and Sctr ${ }^{-1-}$ mice. The pumps were empty on days $8-10$. Data are expressed as the means \pm SEM $(n=6 /$ group). $* 0<0.05$; compared with the respective controls with PBS injection. (c) Plasma Sct level at various time $(2,4$, and 6 h) after i.p. injection of Sct in wt mice. Data are expressed as the means \pm SEM ( $n=6 /$ group).
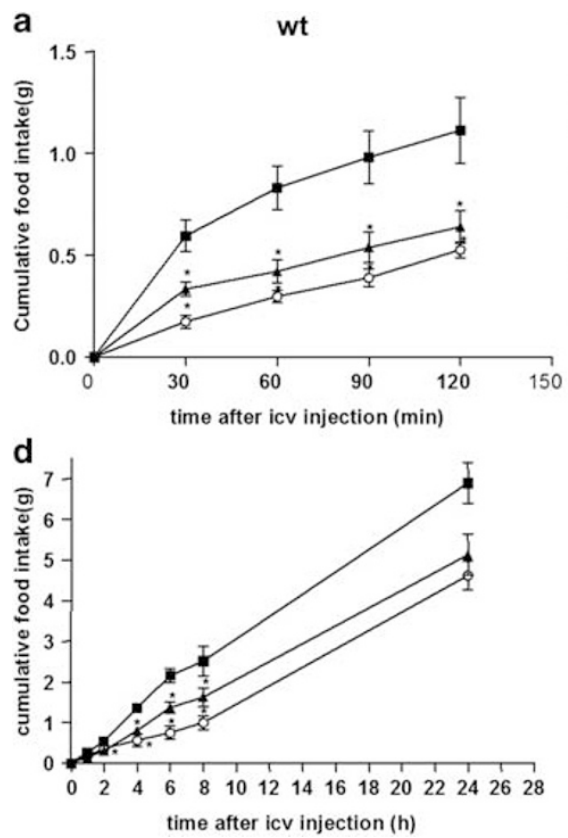
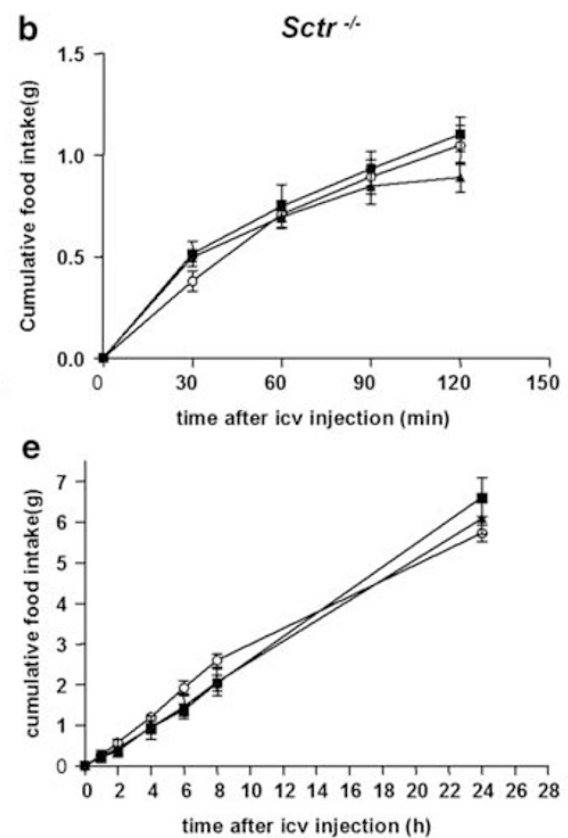
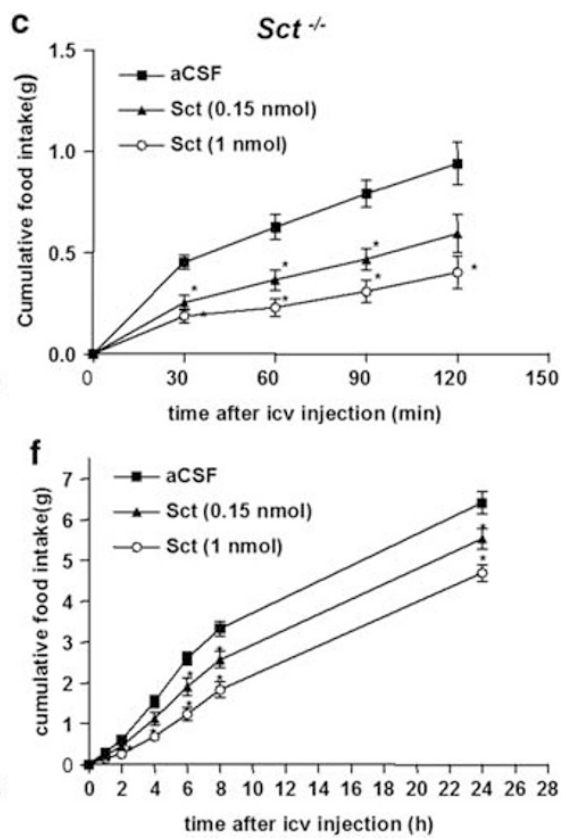

Figure 2 Anorectic effect of central Sct injection in mice. (a-c) Time-course study on the effects of i.c.v.-Sct ( 0.15 and I nmol) or i.c.v.-aCSF (vehicle) on cumulative food intake measured every 30 min during $2 \mathrm{~h}$ in $18 \mathrm{~h}$ fasted (a) $\mathrm{wt}$, (b) Sctr ${ }^{-1-}$, and (c) Sct ${ }^{-1-}$ mice. Data are expressed as the means $\pm \mathrm{SEM}$ ( $n=10 / \mathrm{group}$ ). ( $\mathrm{d}-\mathrm{f}$ ) Time-course study on the effects of i.c.v.-Sct or i.c.v.-aCSF on cumulative food intake at different time (I, 2, 4, 6, 8, and 24h) in ad libitum fed (d) wt, (e) Sctr ${ }^{-l-}$, and (f) $\mathrm{Sct}^{-1-}$ mice. Data are expressed as the means \pm SEM ( $n=10$ /group). ${ }^{*} p<0.05$; compared with the respective control with aCSF injection.

Sct Induces Neuronal Activation in Nuclei Involved in Appetite Control within Hypothalamus and Brainstem

To understand the neuronal pathway that carry out anorectic actions of Sct, the expression of Fos, one of the markers for neuronal activation, was monitored by immunohistochemical examination after central or peripheral injection of Sct. We have previously shown that i.c.v.Sct could induce Fos expression in the PVN and SON in rat brain (Chu et al, 2009), and consistently, we now observed 
a

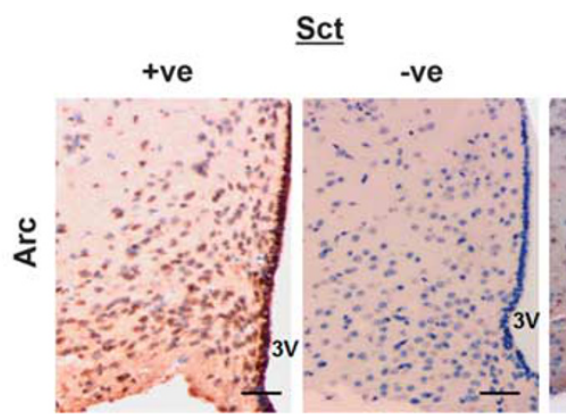

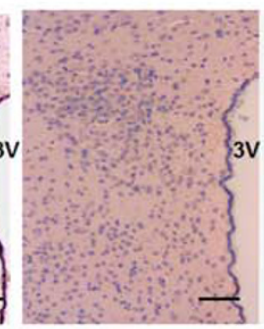

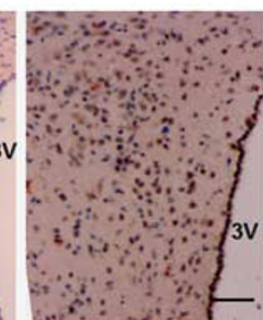

Sctr

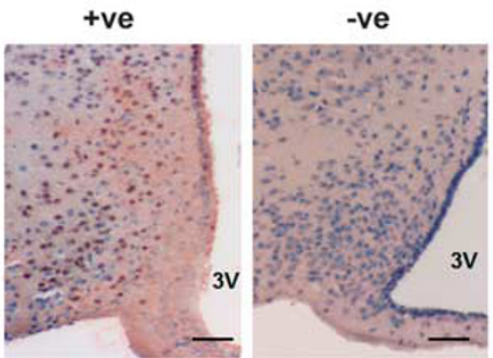

b

$\underline{\text { Sct }}$
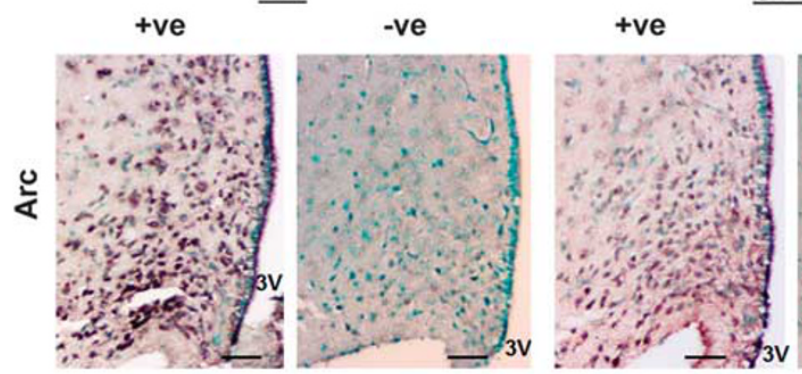

Sctr
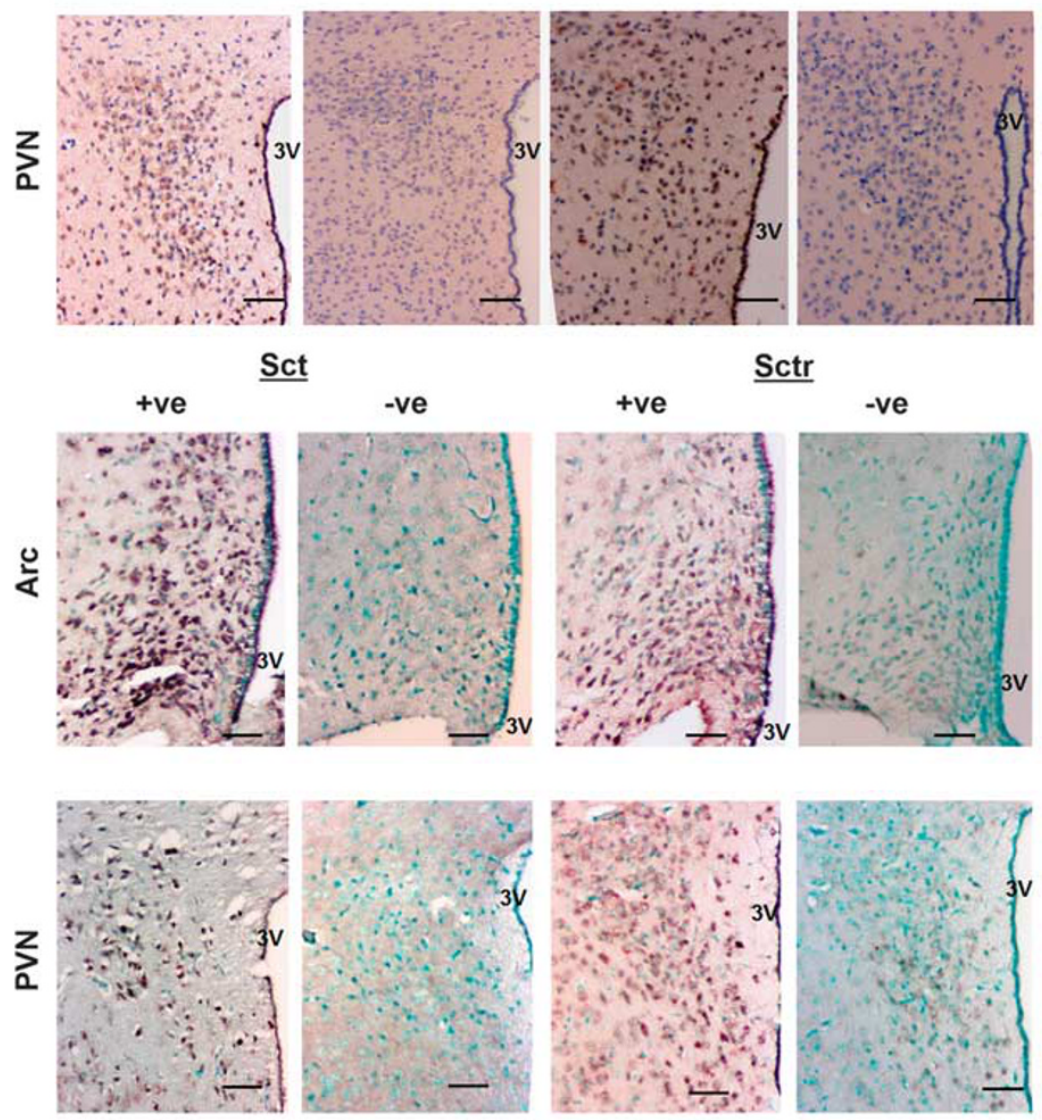

。

-ve
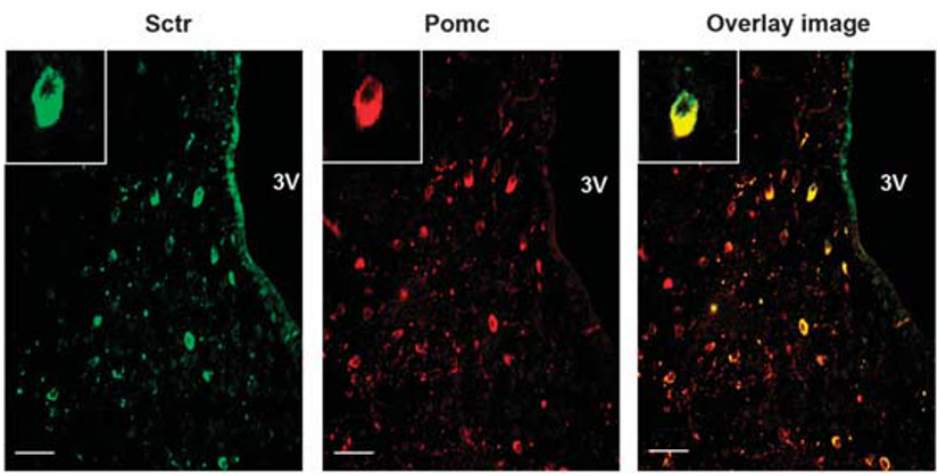

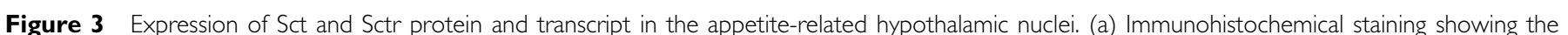

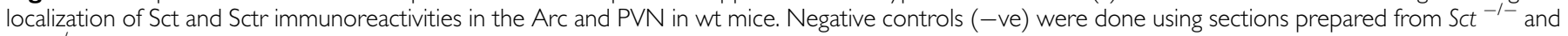

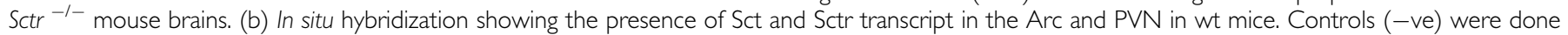
using unlabeled probes for competition $(30 \times)$. (c) Double immunostaining showing the colocalization of Sctr and Pomc neurons in the Arc in wt mice. Negative controls (-ve) were performed using primary Sctr antiserum preabsorbed with 0.1 mM immunizing peptide. Bars, $80 \mu \mathrm{m}$. 
a
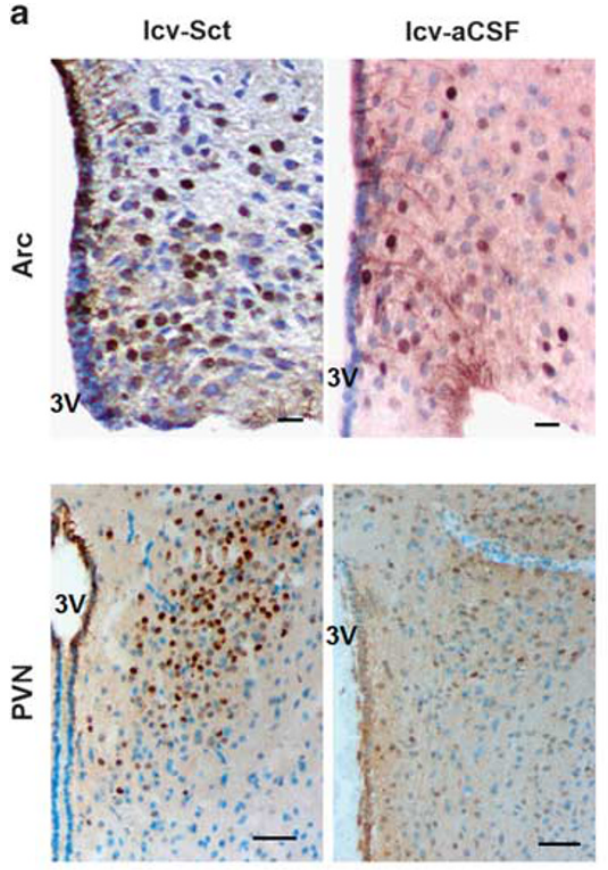
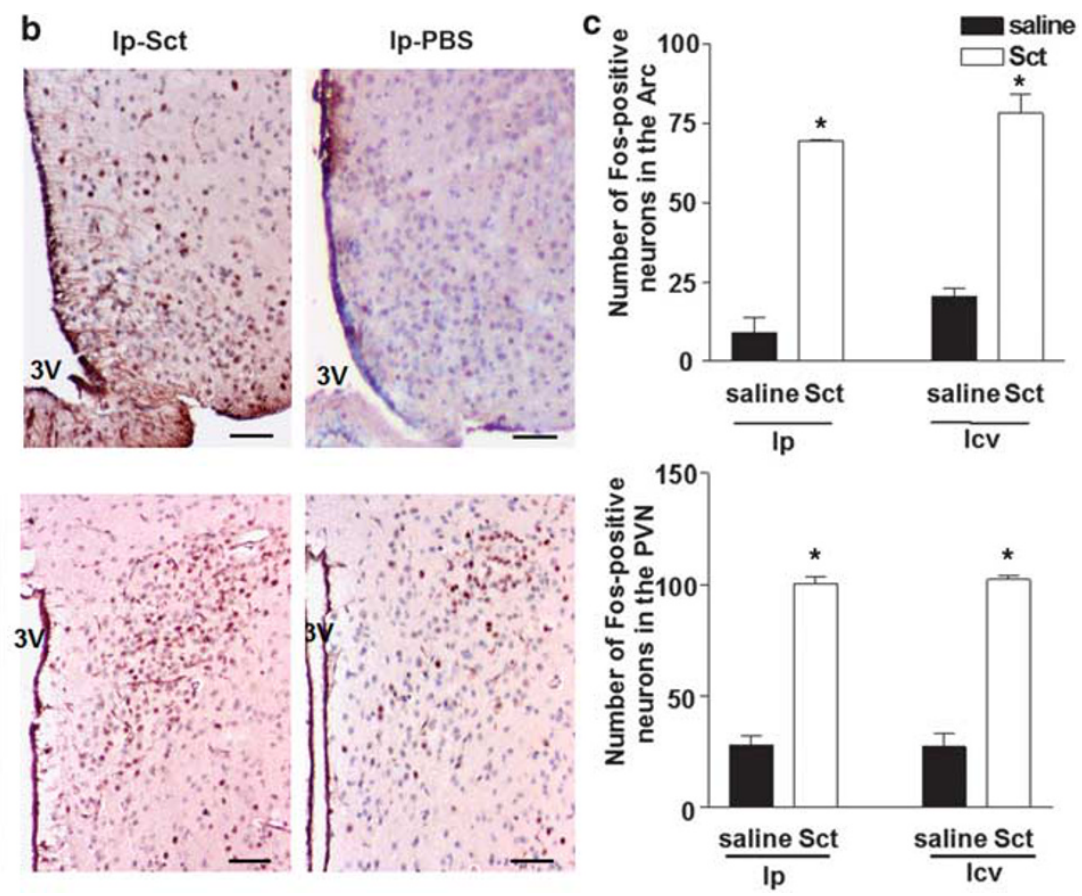

Figure 4 Changes in Fos immunoreactivity upon i.c.v.-Sct and i.p.-Sct. Immunohistochemical staining showing changes in Fos expression in the Arc and PVN upon (a) i.c.v. and (b) i.p.-Sct injection in wt mice. Bars, $80 \mu \mathrm{m}$. (c) The number of Fos immunoreactive cells in the Arc and PVN. Data are expressed as the mean \pm SEM ( $n=5 /$ group). $* p<0.05$, compared with the control with the respective controls with saline injection.

that there was a significant increase in the number of Fos positive cells in the mouse PVN after Sct injection. Additionally, i.c.v.-Sct was also found to stimulate Fos expression in the Arc when compared with the aCSFinjected controls (Figure 4c). Recent research has shown that i.p.-Sct could also cause neuronal activation in many brain regions including the Arc (Yang et al, 2004). Consistently, we have demonstrated that i.p.-Sct $(5 \mathrm{nmol})$ activates Fos expression in the Arc and PVN (Figure 4b). As both central and peripheral administrations of Sct lead to neuronal activation of Arc and PVN, our data suggest that these two areas are potential sites for the anorectic action of Sct.

\section{Sct Modulates Gene Expressions of Feeding-Related Neuropeptides in the Hypothalamic Nuclei}

To further investigate cellular mechanisms involved, the expressions of several key neuropeptides implicated in regulating feeding were measured in Arc and PVN. These areas were isolated by LCM from the brains of i.c.v.-Sct and i.c.v.-aCSF treated mice. We found that i.c.v.-Sct could significantly activate Pomc (2.93-fold, $p<0.05)$ and repress Agrp $(2.50$-fold, $p<0.05)$ mRNA levels in the Arc (Figure 5a), as well as could augment Mc4r (4.12-fold, $p<0.05)$ and Trh $(2.24$-fold; $p<0.05)$ transcripts in the PVN (Figure 5a). Again, these effects of Sct were not found in $\mathrm{Sctr}^{-/-}$mice. In addition, i.c.v.-Sct had no effect also on Cart, Npy, and Crh transcript levels (Figure 5a).

Sctr transcript and protein are detected in the Arc which is in close proximity to the median eminence where blood brain barrier (BBB) is incomplete and peripherally released Sct was also shown to cross the $\mathrm{BBB}$ and reach the brain
(Dogrukol-Ak et al, 2004), therefore it is of great interest to study the effect of peripheral Sct on gene expressions of the central effectors in the hypothalamus. Using the same methodology, the expressions of orexigenic and anorexigenic peptides in Arc and PVN were measured by RT-PCR after i.p.-Sct or i.p.-saline in wt and Sctr ${ }^{-1-}$ mice. Likewise, i.p.-Sct was found to activate Pomc $(2.11$-fold, $p<0.05)$, reduce Agrp mRNA expression $(1.81$-fold, $p<0.05)$ in Arc (Figure 5b), as well as increase Mc4r $(2.78$-fold, $p<0.05)$ and Trh (5.74-fold, $p<0.05$ ) expression in PVN (Figure 5b). In $\mathrm{Sctr}^{-1-}$ mice, no difference was observed between Scttreated and saline-treated control groups (Figure $5 \mathrm{~b}$ ). Both i.c.v. and i.p. showed the same patterns in modulating the expression of various neuropeptides in Arc and PVN, suggesting that they share the same mechanism in inhibiting appetite.

\section{The Anorectic Action of Sct is Mediated via the MC System}

We have shown that Sctr colocalize with Pomc neurons in the Arc, and both i.p.- and i.c.v.-Sct could activate Fos as well as modulate the expression of genes associated with the MC system including Pomc, Agrp, and Mc4r in Arc and PVN. These data suggest that the anorectic effect of Sct could be mediated via the MC system. To test this hypothesis, we injected the Mc4r antagonist, SHU9119, into PVN before i.p.- or i.c.v.-Sct. Intra-PVN injection of SHU9119 (50 pmol) alone had no effect on food intake during the $2 \mathrm{~h}$ period, but it could significantly reduce the i.c.v.-Sct $(0.15 \mathrm{nmol})$-induced suppression of food intake 30 min post-injection (Sct, $0.33 \pm 0.03 \mathrm{~g} v s \mathrm{Sct}+$ SHU9119, $0.57 \pm 0.05 \mathrm{~g} ; p<0.05$; Figure $6 \mathrm{a})$. This effect could be 

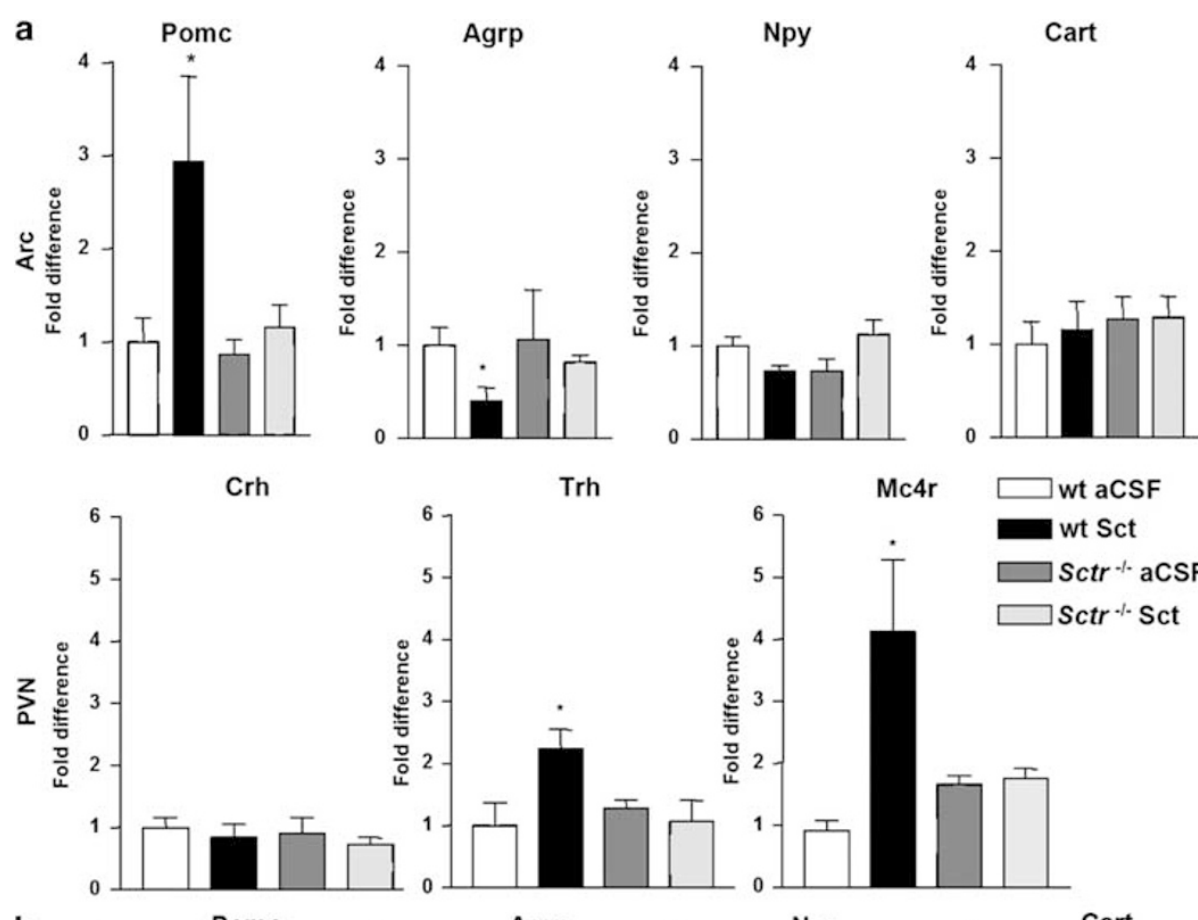

Trh
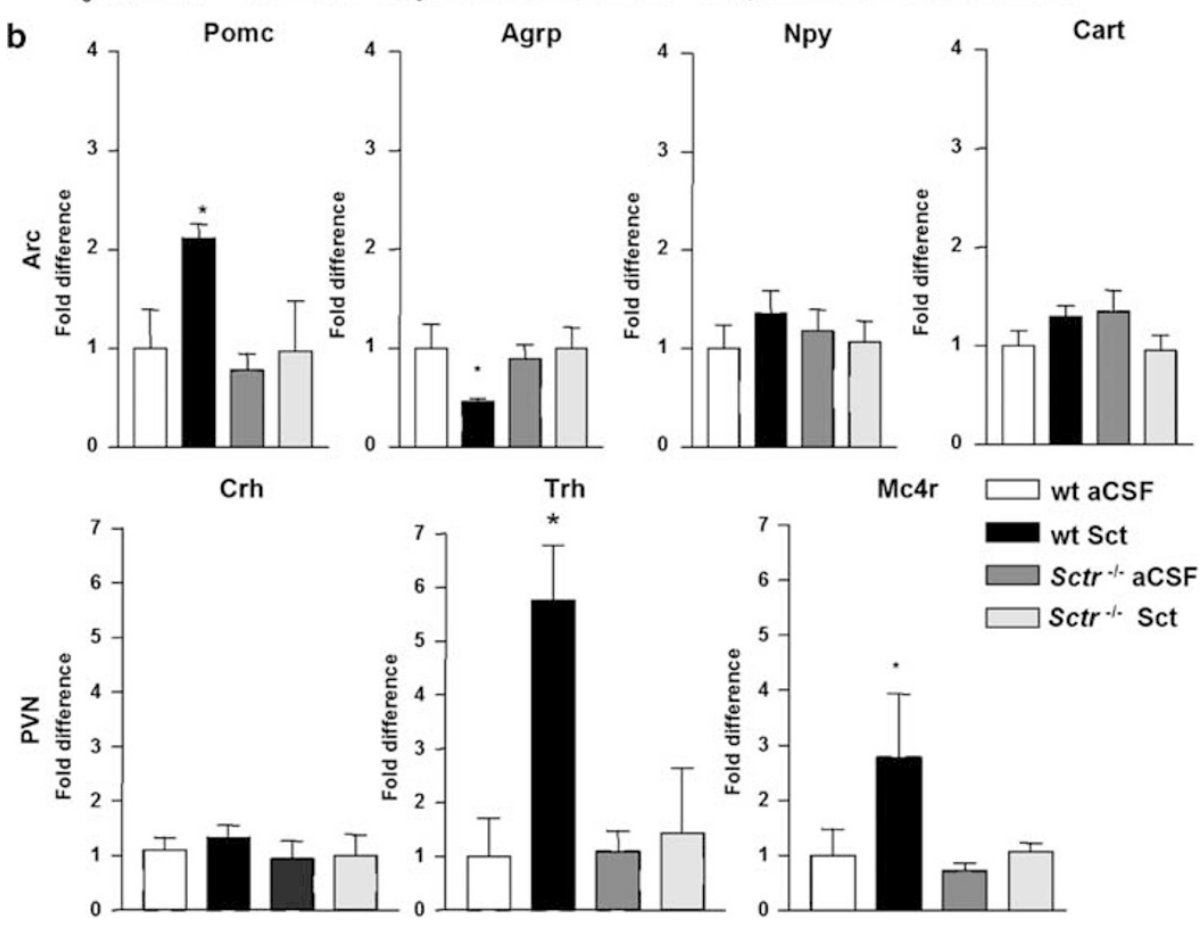

Figure 5 Effects of Sct on gene expressions of neuropeptides. Effects of (a) i.c.v.-Sct and (b) i.p.-Sct on mRNA levels of Pomc, Agrp, Cart, and Npy in the Arc; Trh, Mc4r, and Crh in the PVN. The mRNA levels of the target genes are normalized with Gapdh mRNA levels. Data are expressed as the mean \pm SEM ( $n=6 /$ group). ${ }^{*} p<0.05$; compared with the control with aCSF injection in wt mice.

reproduced in $S c t^{-1-}$ mice (Figure 6c) but not in $\mathrm{Sctr}^{-1-}$ mice (Figure $6 \mathrm{~b}$ ). This effect could be reproduced in $S c t^{-1-}$ mice (Figure 6c) but was not shown in $\mathrm{Sctr}^{-1-}$ mice (Figure 6b). Similarly, i.p.-Sct-induced anorexia was attenuated by SHU9119 injection (Figure 6d). In addition, using double immunohistochemistry, it was found that Sct induced Fos expression in Pomc neurons in the Arc, indicating that Sct activates Pomc pathway to inhibit food intake (Figure 7). Taken together, these data indicated that the anorexia induced by either central or peripheral Sct is at least partly mediated by the MC system.

\section{Peripheral Sct Suppresses Food Intake without Causing a Conditioned Taste Aversion}

Gut hormones may inhibit feeding by causing taste aversion and nausea instead of through a normal physiological process. To determine whether Sct suppresses short-term 

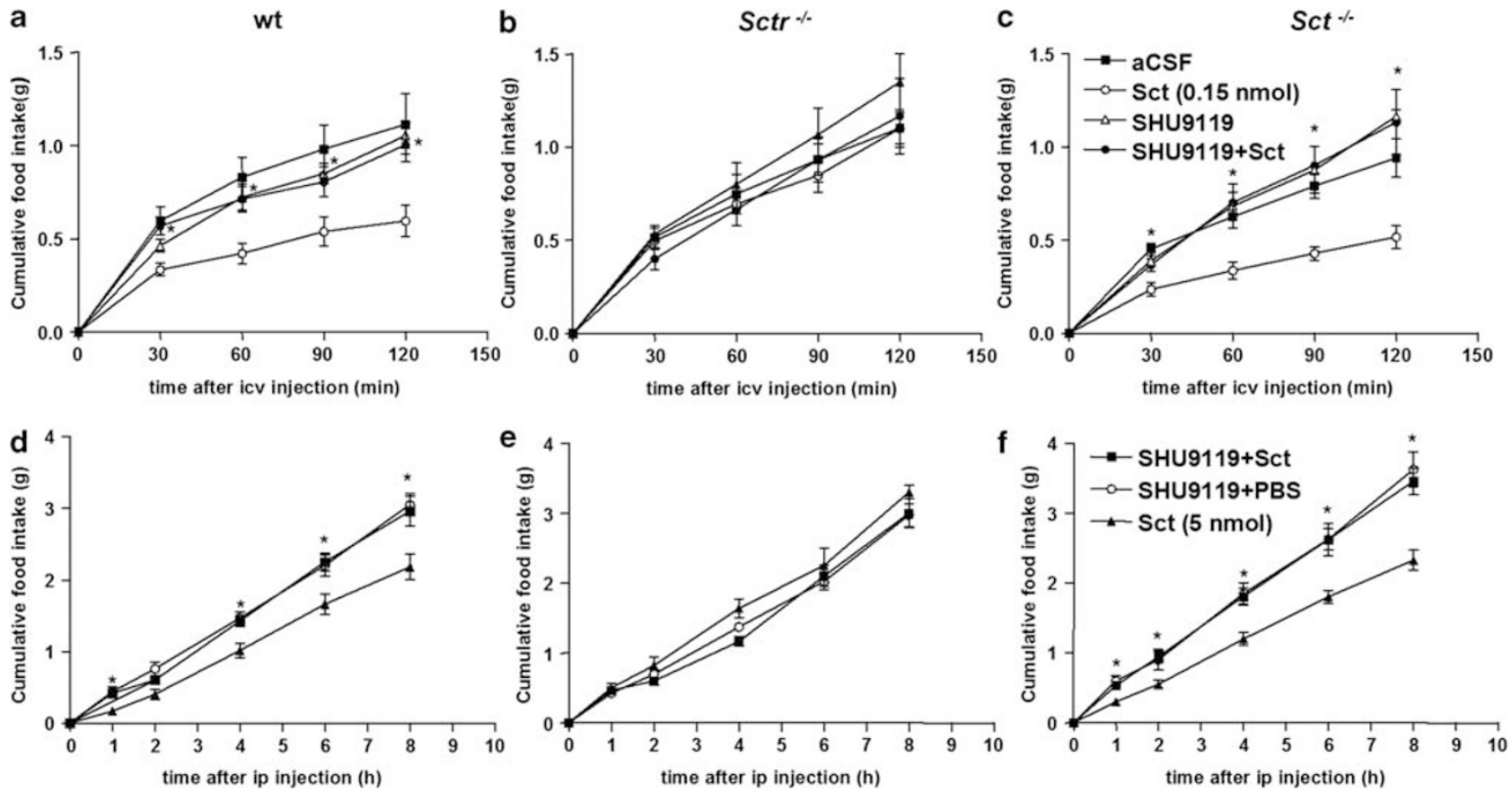

Figure 6 Effect of SHU 9II9 on Sct-induced inhibition of food intake. (a-c) Time course study on the effect of icv-aCSF, icv-Sct, intra-PVN SHU9। I9 or intra-PVN SHU9I 19 before icv-Sct on cumulative food intake measured every 30 min during $2 \mathrm{~h}$ in $18 \mathrm{~h}$ fasted $\mathrm{wt}^{-} \mathrm{Sct}^{-1-}$ and Sctr $^{-1-}$ mice. (d-f) Time course study on the effect of intra-PVN SHU9। 19 before ip-Sct or ip-PBS on cumulative food intake at different time (I, 2, 4, 6, and $8 \mathrm{~h})$ in I8 h fasted wt, $\mathrm{Sctr}^{-1-}$ and Sct ${ }^{-1-}$ mice. Data are expressed as the mean \pm SEM ( $n=8 /$ group). ${ }^{*} p<0.05$, compared with the control with Sct injection in wt mice.

feeding through a normal physiological process or by acting through malaise, the ability of Sct $(5 \mathrm{nmol}$, ip) to serve as the unconditioned stimulus in the development of a conditioned taste aversion was evaluated. Ip injection of $\mathrm{LiCl}$, a known aversive agent, significantly reduced the intake of saccharin solution by mice on the experimental day (Figure 8a). By contrast, mice in both saline and Scttreatment group did not display an aversion to saccharin solution and there was no significant difference in total fluid intake among groups (Figure 8b). In addition, we did not observe adverse behaviors after Sct administration, indicating that the anorectic effect of i.p.-Sct was not caused by drug-induced malaise or other non-specific toxic effect. The plasma Sct levels were monitored 2, 4, and $6 \mathrm{~h}$ after i.p.-Sct $(5 \mathrm{nmol})$ to ensure the dose chosen is not pharmacological. Collectively, our data indicate a physiological relevance of peripheral Sct on appetite control.

\section{DISCUSSION}

Over the past decades, the importance of gut hormones, such as Cck (Gibbs et al, 1973; Kissileff et al, 1981), ghrelin (Nakazato et al, 2001; Tschop et al, 2000; Wren et al, 2001; Wren et al, 2000), and PP (Batterham et al, 2003a, b; Malaisse-Lagae et al, 1977; Ueno et al, 1999), in controlling food intake was recognized. These gut hormones are located ideally to respond to luminal nutrients and their release patterns are altered in response to nutrient ingestion in ways that could affect short and/or long-term appetite. Sct, like many gut-brain peptides, can alter the rate at which nutrients move along the compartments of alimentary canal. In addition, Sct and its receptor are widely expressed in the CNS (Charlton et al, 1981; Köves et al, 2004) including the hypothalamus where energy homeostasis is regulated. In this study, we have shown that Sct and Sctr are expressed in appetite regulating hypothalamic nuclei including the Arc and the PVN. In addition, double immunohistochemical stainings in the Arc show the colocalization of Sctr with Pomc, thus providing an anatomical evidence for a possible anorectic role of Sct. Plasma Sct levels increase when acidic chyme enter the duodenum. The pattern of Sct release suggests a possibility of this peptide, with other gut hormones, in governing anorexia. Consistent with this idea, i.p.- and i.c.v.-Sct could both acutely suppress feeding, whereas a more long-term effect of peripheral Sct on appetite was shown by i.p.infusion of Sct via mini-osmotic pump. In summary, our data suggest that Sct is a potential satiety factor. It may be a novel hypothalamic target for the therapeutic intervention of appetite-related conditions such as obesity.

In the brain, the hypothalamus and the brainstem are the key sites for receiving neuronal and hormonal signals reflecting energy availability. Using Fos as a marker of neuronal activation, we identified specific sites in the brain that are activated by Sct. In the hypothalamus, both i.c.v.and i.p.-Sct injections cause neuronal activation in the Arc and PVN where Sctr and Sct are also expressed, suggesting that these two areas are potential locations for Sct to exert its anorectic actions. More importantly, both i.c.v.- and i.p.Sct are able to modulate transcript levels of several appetiterelated genes in similar manners; it is therefore likely that both central and peripheral Sct utilize comparable mechanism in carrying its function. In summary, in the Arc, Sct 

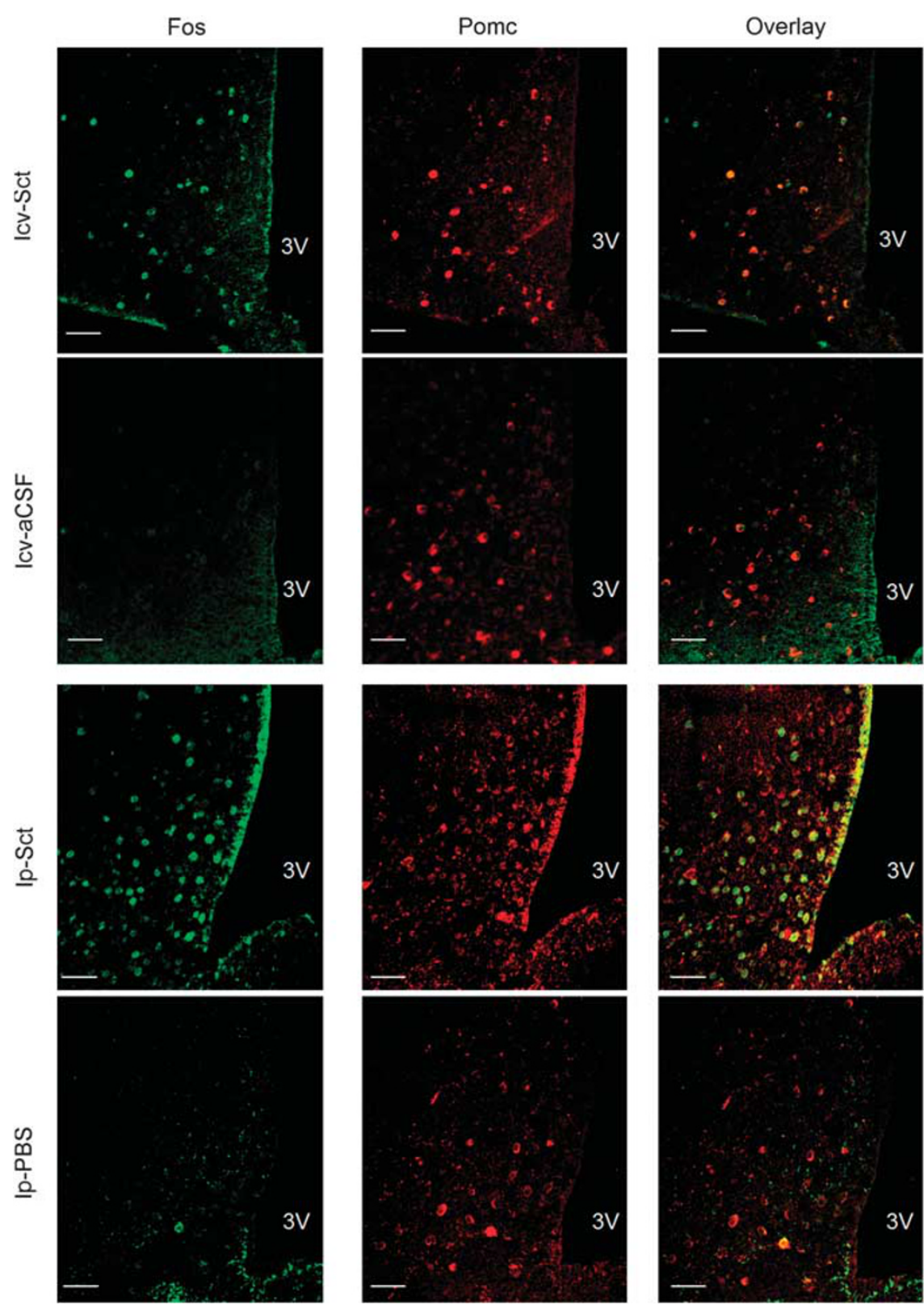

Figure 7 Effect of Sct on Pomc neurons expressing Fos in the Arc. Dark-field micrograph showing Pomc neurons expressing Fos in the Arc upon i.c.v. and i.p.-Sct injection in wt mice. Bars, $80 \mu \mathrm{m}$.
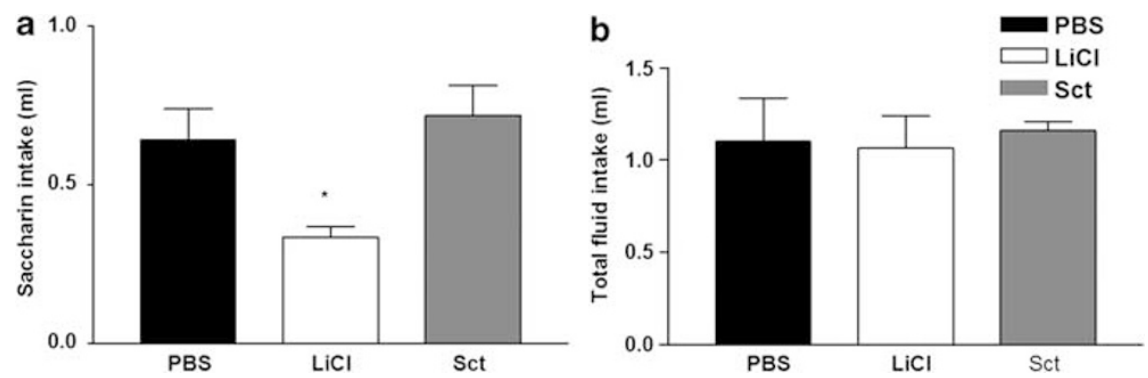

Figure 8 Effect of i.p. injection of Sct in a conditioned taste aversion experiment. Mice received saccharin solution paired with i.p. injection of Sct, LiCl, or saline. Amount of saccharin solution intake (a) and total fluid intake (b) measured during the first 30 min after presentation. Data are expressed as the mean \pm SEM ( $n=5 /$ group). $* p<0.05$, compared with the control with saline injection in wt mice. 
activates Pomc but reduces Agrp transcripts, whereas in the PVN, Sct augments both Trh and Mc4r mRNA levels. The Arc is believed to be an important centre for integrating circulating energy signals via an incomplete BBB (Broadwell and Brightman, 1976; Cone et al, 2001; Peruzzo et al, 2000). There are two primary populations of neurons within Arc, one inhibits food intake through Pomc and Cart (Elias et al, 1998; Kristensen et al, 1998) and the other one stimulates food intake via Npy and Agrp (Broberger et al, 1998; Hahn et al, 1998). The PVN is a critical target innervated by these Arc neurons, Npy/Agrp inhibits (Fekete et al, 2002), whereas $\alpha$-MSH stimulates pro-Trh expression (Fekete et al, 2000), resulting in a catabolic net output. We hypothesize here that Sct activates Pomc neurons in the Arc via Sctr, and one of the products of Pomc, $\alpha-\mathrm{MSH}$, signals downstream to the PVN, leading to food intake reduction.

The central MC system is a well characterized system involved in the regulation of energy balance; it comprises of the proteolytic products of Pomc, their receptors and the endogenous MC antagonists agouti and Agrp. Many regulators of appetite such as leptin (Cowley et al, 2001; Elmquist et al, 1997; Håkansson et al, 1996; Stephens et al, 1995), insulin (Benoit et al, 2002; Sipols et al, 1995; van Houten et al, 1979), and ghrelin (Hewson and Dickson, 2000; Kamegai et al, 2000; Willesen et al, 1999) act through the MC system to modulate energy homeostasis. Our data showed that Sctr is expressed also in Pomc neurons, whereas Sct may function in autocrine, neurocrine, and/or endocrine fashions to modulate expression of peptides and receptors associated with the MC system. As previous injection of SHU9119 into PVN was able to significantly reduce i.c.v.- and i.p.-Sct effects and Sct-induced Fos expression in Pomc neurons in the Arc, it is therefore clear that similar to other regulators, there is also a connection between Sct and the MC system in the CNS.

Sct and Sctr are expressed in discrete endocrine cells and neuronal populations in both gastrointestinal tract and CNS, and in present study, both centrally and peripherally infused Sct were shown to inhibit food intake via similar mechanisms in the hypothalamus, indicating overlapping activities of central and peripheral Sct in controlling food intake. Recently, the neuroactive role of Sct has been increasingly recognized, many studies have shown that Sct is largely produced and expressed in CNS (Chu et al, 2006; Lee et al, 2005; Ng et al, 2002; Welch et al, 2004). In this study, we show that Sct and Sctr are expressed in appetitecontrolling hypothalamic nuclei, and that Sctr co-localizes with the Pomc neurons in Arc. More importantly, injection of Sct into the lateral ventricle inhibits food intake, suggesting that the centrally produced or expressed Sct may function in an autocrine and/or neurocrine manner to exert its anorectic effect. On the other hand, Sct may also act as an endocrine signal to inhibit central food intake. Sct is released from the duodenum by gastric acid (Domschke et al, 1977; Greenberg et al, 1982; Schaffalitzky de Muckadell and Fahrenkrug, 1978) and digested fats (Rhodes et al, 1988). Peripherally released Sct could modify the MC system in the Arc via the vagal primary afferent and/or circulation. It has been shown that Sctr is expressed in the vagal afferents (Yang et al, 2004), and that vagal afferent pathways can mediate effects of Sct, including pancreatic exocrine secretion of fluid and bicarbonate (Gray et al, 1988; Konturek et al, 2003), gastric acid secretion and gastric motility (You and Chey, 1987; Gerber and Payne, 1996; Jin et al, 1994; Shiratori et al, 1992). Additionally, recent studies have demonstrated that peripheral Sct could activate selective brain neurons through this vagal pathway. Ip-Sct was found to induce Fos in the AP and NTS of the brainstem in rats, and this induced Fos expression in the NTS could be blocked by subdiaphragmatic vagotomy (Yang et al, 2004). Consistent with this, we have also found that i.p.-Sct could induce Fos expression in AP and NTS in wt mice (unpublished data), suggesting the presence of a route via vagus to the NTS. Alternatively, circulating Sct could also directly activate neurons in hypothalamic and brainstem centers of appetite control. Sct is capable of crossing the $\mathrm{BBB}$ and reach the brain by transmembrane diffusion in a non-saturable mechanism (Dogrukol-Ak et al, 2004), and Sctr transcript and protein are detected in the Arc (Figure 3) in close proximity to the median eminence where incomplete BBB is described (Broadwell and Brightman, 1976; Cone et al, 2001; Peruzzo et al, 2000). In summary, peripheral Sct may exert its feeding effects by stimulating neurons in the Arc directly, and/or acting via the vagal pathway. The future development of animal models for central- or gut-specific ablation of Sct and/or Sctr would be useful in clarifying the relative roles of central and peripheral Sct on feeding inhibition.

In conclusion, the present study shows for the first time that both central and peripheral Sct administrations, acting through Sctr, are able to inhibit food intake in mice. This function of Sct is mediated, at least in part, via the central MC system. Although the detailed mechanism of the anorectic effect of Sct remains to be fully defined, the present study should draw future attention to the role of Sct in regulating feeding behavior.

\section{ACKNOWLEDGEMENTS}

This work was supported by HK government RGC Grant GRF 763809 and HKU 7566/06 M to BKC Chow.

\section{DISCLOSURE}

The authors declare no conflict of interest.

\section{REFERENCES}

Asakawa A, Inui A, Yuzuriha H, Ueno N, Katsuura G, Fujimiya M et al (2003). Characterization of the effects of pancreatic polypeptide in the regulation of energy balance. Gastroenterology 124: 1325-1336.

Batterham RL, Cohen MA, Ellis SM, Le Roux CW, Roux CW, Withers DJ et al (2003a). Inhibition of food intake in obese subjects by peptide YY3-36. $N$ Engl J Med 349: 941-948.

Batterham RL, Cowley MA, Small CJ, Herzog H, Cohen MA, Dakin CL et al (2002). Gut hormone PYY(3-36) physiologically inhibits food intake. Nature 418: 650-654.

Batterham RL, Le Roux CW, Cohen MA, Park AJ, Ellis SM, Patterson $M$ et al (2003b). Pancreatic polypeptide reduces appetite and food intake in humans. J Clin Endocrinol Metab 88: 3989-3992. 
Bayliss WM, Starling EH (1902). The mechanism of pancreatic secretion. J Physiol 28: 325-353.

Beglinger C, Degen L, Matzinger D, D'Amato M, Drewe J (2001). Loxiglumide, a CCK-A receptor antagonist, stimulates calorie intake and hunger feelings in humans. Am J Physiol Regul Integr Comp Physiol 280: R1149-R1154.

Benoit SC, Air EL, Coolen LM, Strauss R, Jackman A, Clegg DJ et al (2002). The catabolic action of insulin in the brain is mediated by melanocortins. J Neurosci 20: 9048-9052.

Boden G, Essa N, Owen OE, Reichle FA (1974). Effects of intraduodenal administration of $\mathrm{HCl}$ and glucose on circulating immunoreactive secretin and insulin concentrations. J Clin Invest 53: 1185-1193.

Broadwell RD, Brightman MW (1976). Entry of peroxidase into neurons of the central and peripheral nervous systems from extracerebral and cerebral blood. J Comp Neurol 166: 257-283.

Broberger C, Johansen J, Johansson C, Schalling M, Hokfelt T (1998). The neuropeptide Y/agouti gene-related protein (AGRP) brain circuitry in normal, anorectic, and monosodium glutamate-treated mice. Proc Natl Acad Sci USA 95: 15043-15048.

Challis BG, Pinnock SB, Coll AP, Carter RN, Dickson SL, O'Rahilly S (2003). Acute effects of PYY3-36 on food intake and hypothalamic neuropeptide expression in the mouse. Biochem Biophys Res Commun 311: 915-919.

Charlton CG, O'Donohue TL, Miller RL, Jacobowitz DM (1981). Secretin immunoreactivity in rat and pig brain. Peptides 2(Suppl 1): 45-49.

Chisholm DJ, Young JD, Lazarus L (1969). The gastrointestinal stimulus to insulin release. I. Secretin. J Clin Invest 48: 1453-1460.

Chu JY, Lee LT, Lai CH, Vaudry H, Chan YS, Yung WH et al (2009). Secretin as a neurohypophysial factor regulating body water homeostasis. Proc Natl Acad Sci USA 106: 15961-15966.

Chu JY, Yung WH, Chow BK (2006). Endogenous release of secretin from the hypothalamus. Ann N Y Acad Sci 1070: 196-200.

Cohen MA, Ellis SM, Le Roux CW, Batterham RL, Park A, Patterson $\mathrm{M}$ et al (2003). Oxyntomodulin suppresses appetite and reduces food intake in humans. J Clin Endocrinol Metab 88: $4696-4701$.

Cone RD, Cowley MA, Butler AA, Fan W, Marks DL, Low MJ (2001). The arcuate nucleus as a conduit for diverse signals relevant to energy homeostasis. Int J Obes Relat Metab Disord 5: S63-S67.

Cowley MA, Smart JL, Rubinstein M, Cerdán MG, Diano S, Horvath TL et al (2001). Leptin activates anorexigenic POMC neurons through a neural network in the arcuate nucleus. Nature 411: 480-484.

Dakin CL, Small CJ, Park AJ, Seth A, Ghatei MA, Bloom SR (2002). Repeated ICV administration of oxyntomodulin causes a greater reduction in body weight gain than in pair-fed rats. Am J Physiol Endocrinol Metab 283: E1173-E1177.

Dakin CL, Gunn I, Small CJ, Edwards CM, Hay DL, Smit h DM et al (2001). Oxyntomodulin inhibits food intake in the rat. Endocrinology 142: 4244-4250.

Dakin CL, Small CJ, Batterham RL, Neary NM, Cohen MA, Patterson $M$ et al (2004). Peripheral oxyntomodulin reduces food intake and body weight gain in rats. Endocrinology 145: 2687-2695.

Diaco JF, Miller LD, Kuo PT, Feng LY, Sugerman HJ (1971). Effects of secretin on serum immunoreactive insulin and insulin-like activity. Ann Surg 173: 578-582.

Dogrukol-Ak D, Tore F, Tuncel N (2004). Passage of VIP/PACAP/ secretin family across the blood-brain barrier: therapeutic effects. Curr Pharm Des 10: 1325-1340.

Domschke W, Greenberg GR, Domschke S, Bloom SR, Mitznegg P, Sprugel W et al (1977). Endogenous acid releases secretin in man. Acta Hepatogastroenterol (Stuttg) 24: 262-263.
Elias CF, Lee C, Kelly J, Aschkenasi C, Ahima RS, Couceyro PR et al (1998). Leptin activates hypothalamic CART neurons projecting to the spinal cord. Neuron 21: 1375-1385.

Elmquist JK, Ahima RS, Maratos-Flier E, Flier JS, Saper CB (1997). Leptin activates neurons in ventrobasal hypothalamus and brainstem. Endocrinology 138: 839-842.

Fekete C, Légrádi G, Mihály E, Huang QH, Tatro JB, Rand WM et al (2000). alpha-Melanocyte-stimulating hormone is contained in nerve terminals innervating thyrotropin-releasing hormone-synthesizing neurons in the hypothalamic paraventricular nucleus and prevents fasting-induced suppression of prothyrotropin-releasing hormone gene expression. J Neurosci 20: $1550-1558$.

Fekete C, Sarkar S, Rand WM, Harney JW, Emerson CH, Bianco AC et al (2002). Agouti-related protein (AGRP) has a central inhibitory action on the hypothalamic-pituitary-thyroid (HPT) axis; comparisons between the effect of AGRP and neuropeptide $\mathrm{Y}$ on energy homeostasis and the HPT axis. Endocrinology 143: 3846-3853.

Gerber JG, Payne NA (1996). Secretin inhibits canine gastric acid secretion in response to pentagastrin by modulating gastric histamine release. J Pharmacol Exp Ther 279: 718-723.

Gibbs J, Young RC, Smith GP (1973). Cholecystokinin decreases food intake in rats. J Comp Physiol Psychol 84: 488-495.

Glick Z, Thomas DW, Mayer J (1971). Absence of effect of injections of the intestinal hormones secretin and choecystokinin-pancreozymin upon feeding behavior. Physiol Behav 6: 5-8.

Gray MA, Greenwell JR, Argent BE (1988). Secretin-regulated chloride channel on the apical plasma membrane of pancreatic duct cells. J Membr Biol 105: 131-142.

Greenberg GR, McCloy RF, Baron JH, Bryant MG, Bloom SR (1982). Gastric acid regulates the release of plasma secretin in man. Eur J Clin Invest 12: 361-372.

Grovum WL (1981). Factors affecting the voluntary intake of food by sheep. 3. The effect of intravenous infusions of gastrin, cholecystokinin and secretin on motility of the reticulo-rumen and intake. Br J Nutr 45: 183-201.

Håkansson ML, Hulting AL, Meister B (1996). Expression of leptin receptor mRNA in the hypothalamic arcuate nucleus-relationship with NPY neurones. Neuroreport 7: 3087-3092.

Hahn TM, Breininger JF, Baskin DG, Schwartz MW (1998) Coexpression of Agrp and NPY in fasting-activated hypothalamic neurons. Nat Neurosci 1: 271-272.

Hewson AK, Dickson SL (2000). Systemic administration of ghrelin induces Fos and Egr-1 proteins in the hypothalamic arcuate nucleus of fasted and fed rats. J Neuroendocrinol 12: 1047-1049.

Hewson G, Leighton GE, Hill RG, Hughes J (1988). The cholecystokinin receptor antagonist L364,718 increases food intake in the rat by attenuation of the action of endogenous cholecystokinin. Br J Pharmacol 93: 79-84.

Jin HO, Lee KY, Chang TM, Chey WY, Dubois A (1994). Secretin: a physiological regulator of gastric emptying and acid output in dogs. Am J Physiol 267(4 Pt 1): G702-G708.

Köves K, Kausz M, Reser D, Illyés G, Takács J, Heinzlmann A et al (2004). Secretin and autism: a basic morphological study about the distribution of secretin in the nervous system. Regul Pept 123: 209-216.

Kamegai J, Tamura H, Shimizu T, Ishii S, Sugihara H, Wakabayashi I (2000). Central effect of ghrelin, an endogenous growth hormone secretagogue, on hypothalamic peptide gene expression. Endocrinology 141: 4797-4800.

Kanno N, LeSage G, Glaser S, Alpini G (2001). Regulation of cholangiocyte bicarbonate secretion. Am J Physiol Gastrointest Liver Physiol 281: G612-G625.

Kissileff HR, Pi-Sunyer FX, Thornton J, Smith GP (1981). Cterminal octapeptide of cholecystokinin decreases food intake in man. Am J Clin Nutr 34: 154-160. 
Kofod H (1986). Secretin N-terminal hexapeptide potentiates insulin release in mouse islets. Regul Pept 15: 229-237.

Konturek SJ, Zabielski R, Konturek JW, Czarnecki J (2003). Neuroendocrinology of the pancreas; role of brain-gut axis in pancreatic secretion. Eur J Pharmacol 481: 1-14.

Kraegen EW, Chisholm DJ, Young JD, Lazarus L (1970). The gastrointestinal stimulus to insulin release. II. A dual action of secretin. J Clin Invest 49: 524-529.

Kristensen P, Judge ME, Thim L, Ribel U, Christjansen KN, Wulff BS et al (1998). Hypothalamic CART is a new anorectic peptide regulated by leptin. Nature 393: 72-76.

Lee SM, Chen L, Chow BK, Yung WH (2005). Endogenous release and multiple actions of secretin in the rat cerebellum. Neuroscience 134: 377-386.

Lerner RL, Porte Jr D (1970). Uniphasic insulin responses to secretin stimulation in man. J Clin Invest 49: 2276-2280.

Lerner RL, Porte Jr D (1972). Studies of secretin-stimulated insulin responses in man. J Clin Invest 51: 2205-2210.

Malaisse-Lagae F, Carpentier JL, Patel YC, Malaisse WJ, Orci L (1977). Pancreatic polypeptide: a possible role in the regulation of food intake in the mouse. Hypothesis. Experientia 33: 915-917.

Meeran K, O'Shea D, Edwards CM, Turton MD, Heath MM, Gunn I et al (1999). Repeated intracerebroventricular administration of glucagon-like peptide-1-(7-36) amide or exendin-(9-39) alters body weight in the rat. Endocrinology 140: 244-250.

Nakazato M, Murakami N, Date Y, Kojima M, Matsuo H, Kangawa $\mathrm{K}$ et al (2001). A role for ghrelin in the central regulation of feeding. Nature 409: 194-198.

$\mathrm{Ng}$ SS, Yung WH, Chow BK (2002). Secretin as a neuropeptide. $\mathrm{Mol}$ Neurobiol 26: 97-107.

Nussdorfer GG, Bahcelioglu M, Neri G, Malendowicz LK (2000). Secretin, glucagon, gastric inhibitory polypeptide, parathyroid hormone, and related peptides in the regulation of the hypothalamus- pituitary-adrenal axis. Peptides 21: 309-324.

O’Donohue TL, Charlton CG, Miller RL, Boden G, Jacobowitz DM (1981). Identification, characterization, and distribution of secretin immunoreactivity in rat and pig brain. Proc Natl Acad Sci USA 78: 5221-5224.

Paxinos G, Franklin KB (2001). The Mouse Brain in Stereotaxic Coordinates. Academic Press: San Diego.

Peruzzo B, Pastor FE, Blázquez JL, Schöbitz K, Peláez B, Amat P et al (2000). A second look at the barriers of the medial basal hypothalamus. Exp Brain Res 132: 10-26.

Rhodes RA, Skerven G, Chey WY, Chang TM (1988). Acidindependent release of secretin and cholecystokinin by intraduodenal infusion of fat in humans. Pancreas 3: 391-398.

Rodbell M, Birnbaumer L, Pohl SL (1970). Adenyl cyclase in fat cells. 3. Stimulation by secretin and the effects of trypsin on the receptors for lipolytic hormones. J Biol Chem 245: 718-722.

Rudman D, Del Rio AE (1969). Lipolytic activity of synthetic porcine secretin. Endocrinology 85: 214-217.

Schaffalitzky de Muckadell OB, Fahrenkrug J (1978). Secretion pattern of secretin in man: regulation by gastric acid. Gut 19: 812-818.

Shiratori K, Watanabe S, Takeuchi T (1992). Role of endogenous secretin and cholecystokinin in intraduodenal oleic acid-induced inhibition of gastric acid secretion in rats. Dig Dis Sci 37: 397-402.

Sipols AJ, Baskin DG, Schwartz MW (1995). Effect of intracerebroventricular insulin infusion on diabetic hyperphagia and hypothalamic neuropeptide gene expression. Diabetes 44: 147-151.

Stephens TW, Basinski M, Bristow PK, Bue-Valleskey JM, Burgett SG, Craft L et al (1995). The role of neuropeptide $\mathrm{Y}$ in the antiobesity action of the obese gene product. Nature 377: $530-532$
Tamura H, Kamegai J, Shimizu T, Ishii S, Sugihara H, Oikawa S (2002). Ghrelin stimulates GH but not food intake in arcuate nucleus ablated rats. Endocrinology 143: 3268-3275.

Tang-Christensen M, Vrang N, Larsen PJ (2001). Glucagon-like peptide containing pathways in the regulation of feeding behaviour. Int J Obes Relat Metab Disord 25(Suppl 5): S42-S47.

Tay J, Goulet M, Rusche J, Boismenu R (2004). Age-related and regional differences in secretin and secretin receptor mRNA levels in the rat brain. Neurosci Lett 366: 176-181.

Tschop M, Smiley DL, Heiman ML (2000). Ghrelin induces adiposity in rodents. Nature 407: 908-913.

Tschop M, Smiley DL, Heiman ML (2000). Ghrelin induces adiposity in rodents. Nature 407: 908-913.

Turton MD, O'Shea D, Gunn I, Beak SA, Edwards CM, Meeran K et al (1996). A role for glucagon-like peptide-1 in the central regulation of feeding. Nature 379: 69-72.

Ueno N, Inui A, Iwamoto M, Kaga T, Asakawa A, Okita $\mathrm{M}$ et al (1999). Decreased food intake and body weight in pancreatic polypeptide-overexpressing mice. Gastroenterology 117: 1427-1432.

van Houten M, Posner BI, Kopriwa BM, Brawer JR (1979). Insulinbinding sites in the rat brain: in vivo localization to the circumventricular organs by quantitative radioautography. Endocrinology 105: 666-673.

Vaudry D, Gonzalez BJ, Basille M, Yon L, Fournier A, Vaudry H (2000). Pituitary adenylate cyclase-activating polypeptide and its receptors: from structure to functions. Pharmacol Rev 52: 269-324.

Verdich C, Flint A, Gutzwiller JP, Naslund E, Beglinger C, Hellstrom PM et al (2001). A meta-analysis of the effect of glucagon-like peptide-1 (7-36) amide on ad libitum energy intake in humans. J Clin Endocrinol Metab 86: 4382-4389.

Wang L, Saint-Pierre DH, Tache Y (2002). Peripheral ghrelin selectively increases Fos expression in neuropeptide $\mathrm{Y}$ - synthesizing neurons in mouse hypothalamic arcuate nucleus. Neurosci Lett 325: 47-51.

Welch MG, Keune JD, Welch-Horan TB, Anwar N, Anwar M, Ludwig RJ et al (2004a). Secretin: hypothalamic distribution and hypothesized neuroregulatory role in autism. Cell Mol Neurobiol 24: 219-241.

Welch MG, Keune JD, Welch-Horan TB, Anwar N, Anwar M, Ludwig RJ et al (2004b). Secretin: hypothalamic distribution and hypothesized neuroregulatory role in autism. Cell Mol Neurobiol 24: $219-241$.

WHO (2010). Obesity and Overweight-Facts about Overweight and Obesity. WHO: Geneva.

Willesen MG, Kristensen P, Romer J (1999). Co-localization of growth hormone secretagogue receptor and NPY mRNA in the arcuate nucleus of the rat. Neuroendocrinology 70: 306-316.

Wren AM, Small CJ, Abbott CR, Dhillo WS, Seal LJ, Cohen MA et al (2001). Ghrelin causes hyperphagia and obesity in rats. Diabetes 50: 2540-2547.

Wren AM, Small CJ, Ward HL, Murphy KG, Dakin CL, Taheri S et al (2000). The novel hypothalamic peptide ghrelin stimulates food intake and growth hormone secretion. Endocrinology 141: 4325-4328.

Yamamoto H, Kishi T, Lee CE, Choi BJ, Fang H, Hollenberg AN et al (2003). Glucagon-like peptide-1-responsive catecholamine neurons in the area postrema link peripheral glucagon-like peptide-1 with central autonomic control sites. J Neurosci 23: 2939-2946.

Yang H, Wang L, Wu SV, Tay J, Goulet M, Boismenu R et al (2004). Peripheral secretin-induced Fos expression in the rat brain is largely vagal dependent. Neuroscience 128: 131-141.

You CH, Chey WY (1987). Secretin is an enterogastrone in humans. Dig Dis Sci 32: 466-471. 